\title{
Is thyroid stimulating hormone titration mandatory in the routine work-up of African males from infertile couples?
}

\author{
Jean D. Kemfang Ngowa ${ }^{1 *}$, Yvan S. Ngaha Tchawe², Esther V. Voundi ${ }^{3}$, Michel Toukam³, \\ Anny Ngassam ${ }^{1}$, Cyrille C. Noa ${ }^{1}$, Christiane Nshalai ${ }^{1}$, Junie Metogo ${ }^{1}$, Eugene Sobngwi ${ }^{4}$
}

${ }^{1}$ Department of Obstetrics and Gynaecology, ${ }^{2}$ Faculty of Medicine and Biomedical Sciences, ${ }^{3}$ Department of Clinical Biology, ${ }^{4}$ Department of Medicine, University of Yaounde 1, Cameroon

Received: 08 August 2020

Accepted: 09 September 2020

\section{*Correspondence:}

Dr. Jean D. Kemfang Ngowa,

E-mail: jdkemfang@yahoo.fr

Copyright: () the author(s), publisher and licensee Medip Academy. This is an open-access article distributed under the terms of the Creative Commons Attribution Non-Commercial License, which permits unrestricted non-commercial use, distribution, and reproduction in any medium, provided the original work is properly cited.

\section{ABSTRACT}

Background: The impact of thyroid hormones on male reproductive function is still insufficiently understood. The objectives of this study were to determine the frequency of thyroid dysfunction in men from infertile couples and to establish an association between TSH (thyroid stimulating hormone) values and sperm parameters.

Methods: We conducted a cross-sectional analytical study on a consecutive series of men managed for couple infertility in two reference hospitals of Yaoundé from November 2017 to May 2018. For each participant, a questionnaire was administered, TSH was assayed using electro-chemo-luminescence and sperm analyzed. Statistical methods used were the Mann-Whitney test and the Spearman correlation coefficient with a significance threshold of $5 \%$.

Results: Overall, 123 men were recruited. The median age was 44 years old [38-50 years]; 60 (48.79\%) patients had couple infertility lasting between 1 and 5 years. Primary infertility of the couple was the most common $(82$ cases, $66.70 \%)$. After sperm analysis, 86 patients $(70 \%)$ had one or more anomalies. TSH titration revealed $03(2.44 \%)$ cases of subclinical hyperthyroidism, 05 (4.06\%) subclinical hypothyroidism and 115 (93.50\%) euthyroidism. Significant associations were found between TSH and sperm parameters in the group of patients with thyroid dysfunction, but none in the euthyroid group.

Conclusions: Frequency of dysthyroidism is low among African males from infertile couples. We noted significant correlations between TSH values and sperm parameters. The low frequency of thyroid dysfunction would be against a TSH titration in the routine work-up of these patients.

Keywords: Infertility, Male, Sperm, Dysthyroidism, Thyroid stimulating hormone

\section{INTRODUCTION}

The general effect of thyroid hormones is to activate nuclear transcription of large numbers of genes in virtually all cells of the body leading to an increase in cell metabolism and body growth. ${ }^{1}$ Although testes have been considered for many years to be organs that do not respond to thyroid hormones, it is now accepted that these hormones play an important role in the development and physiology of the testes. ${ }^{2,3}$ Several pieces of evidence reveal that thyroid hormones influence steroidogenesis, spermatogenesis, and sperm fluid production. ${ }^{4-13}$ In addition, despite the fact that the mechanism of action of these hormones on testes has not yet been pinpointed, recent studies agree on the existence of thyroid hormone receptors in human testes. ${ }^{14,15}$ This suggests that abnormalities of thyroid function could be an aetiology of male infertility. 
Thyrotropin, also known as thyroid stimulating hormone (TSH), is the first-line hormone used to evaluate the thyroid function of patients because slight changes in this function are typically associated with a significant rise or fall in TSH levels. ${ }^{16}$ Thus, measuring TSH levels is useful for guiding the practitioner on the actual presence of clinical or subclinical dysthyroidism. In the African setting where access to care is hampered by lack of financial means, evaluation of thyroid function is rarely conducted in male patients followed for infertility of the couple. The objectives of this study were to determine the prevalence of thyroid dysfunction in men managed for infertility of the couple and to look for an association between TSH levels and sperm parameters, in order to know if systematic screening of thyroid disorders should be undertaken in our context.

\section{METHODS}

An analytical cross-sectional study was conducted over a period of 07 months (November 2017-May 2018). The target population consisted of all men being followed up for infertility of the couple. We recruited in two reference centres of Yaoundé, Cameroon: the Gynaecological Endoscopic Surgery and Human Reproductive Teaching Hospital (CHRACERH) and the Gynaeco-obstetrics and Paediatrics Hospital of Yaoundé (HGOPY).

After obtaining administrative authorisations and ethical clearance, patients were approached to present the study. Those who consented to participate in the study were asked to sign a free, informed consent form.

Sampling was non-probabilistic and consecutive during the study period. Some patients were excluded because they were under medical treatment that could interfere with thyroid or reproductive function (testosterone, chemotherapy, levothyroxine, amiodarone, propylthio uracil, methimazole, antipsychotics or neuroleptics). In addition, patients who had a febrile episode seven days prior to recruitment, those with symptoms of a genital infection three months prior, or whose semen analysis revealed polynuclear cells greater than $10^{9} / 1$ and/or bacteria were excluded from the study. We also excluded all those who had undergone a vasectomy or a unilateral or bilateral orchiectomy.

We collected data from our target population by administering a questionnaire and collecting blood and sperm samples from each patient. Blood samples were collected in dry tubes to determine TSH values by electro-chemo-luminescence. These values were interpreted according to the 2012 AACE-ATA (American association of clinical endocrinologists- American thyroid association) cosponsored guidelines with upper and lower limits of $4.12 \mathrm{mIU} / 1$ and $0.45 \mathrm{mIU} / \mathrm{l}$, respectively. ${ }^{17}$ Semen was collected by masturbation after blood sampling. Semen collection, analysis and interpretation protocols were consistent with the WHO
2010 recommendations whose reference values are shown in (Table 1). ${ }^{18}$

Table 1: Lower reference limits for semen characteristics according to WHO 2010 standards.

\begin{tabular}{|l|l|}
\hline Semen parameters & $\begin{array}{l}\text { Lower reference } \\
\text { limits }\end{array}$ \\
\hline Volume $(\mathbf{m l})$ & $1.5(1.4-1.7)$ \\
\hline Sperm count $(* \mathbf{1 0} / \mathbf{m l})$ & $15(12-16)$ \\
\hline Sperm count $(* \mathbf{1 0} / \mathbf{e j a c u l a t e})$ & $39(33-46)$ \\
\hline Progressive motility $(\boldsymbol{\%})$ & $32(31-34)$ \\
\hline Total motility $(\mathbf{\%})$ & $40(38-42)$ \\
\hline Vitality $(\%)$ & $58(55-63)$ \\
\hline Normal forms $(\boldsymbol{\%})$ & $4(3.0-4.0)$ \\
\hline
\end{tabular}

The clinical variables of interest included the sociodemographic characteristics of the population, the type and duration of the couple's infertility, semen parameters and TSH values.

Data analysis was done using SPSS software version 23.0 with significance threshold set at 5\%. We used frequencies or parameters of central tendency and dispersion. The frequency of dysthyroidism was determined in the study population and in the abnormal sperm group.

Variables were divided into two subgroups, normal and abnormal for sperm parameters, according to WHO 2010 standards. In each subgroup, we calculated median TSH levels, and compared the subgroups using the MannWhitney U test. Finally, we determined the Spearman (r) correlation coefficient between sperm parameters and TSH values in each subgroup of the sample (hypo-, hyper- and euthyroid subgroups) and in the total sample.

\section{RESULTS}

Overall, 123 male patients were included in this study. The median age was 44 years old with the 1 st and 3 rd quartile being respectively, 38 and 50 years. Most of them were married $(79.68 \%)$. The duration of couple infertility was mostly between 1 and 5 years $(48.79 \%)$. Primary infertility of the couple was most common $(66.70 \%)$. (Table 2) shows all socio-demographic and clinical data of the study population.

Semen analysis found that $70 \%$ of patients had abnormal semen, $49.09 \%$ of patients had low sperm count and $2.44 \%$ of patients had azoospermia. A third of patients had oligoasthenonecrozoospermia (OAT) while teratozoospermia was absent. (Table 3) presents the semen characteristics of the patients recruited.

TSH assays revealed that there were $08(6.50 \%)$ patients with dysthyroidism, amongst which $05(4.06 \%)$ cases of hypothyroidism and $03 \quad(2.44 \%)$ cases of hyperthyroidism. Euthyroidism was found in 115 
$(93.50 \%)$ cases. None of these patients presented clinical signs of dysthyroidism. Distribution of thyroid function according to semen parameter status found a similar occurrence of dysthyroidism in the two subgroups of normal and abnormal semen. In fact, 04 cases of subclinical thyroid dysfunction were diagnosed in each subgroup. This corresponds to $4.65 \%$ of patients with abnormal semen and $10.81 \%$ of patients with normal semen. Furthermore, patients with hyperthyroidism presented normal semen and those with hypothyroidism did not present a specific distribution of semen parameters. Detailed Results are shown in (Table 4).

Table 2: Socio-demographic and clinical data.

\begin{tabular}{|lll|}
\hline Characteristics & $\begin{array}{l}\text { Frequencies } \\
(\mathbf{n = 1 2 3})\end{array}$ & Percentage \\
\hline Marital status & & \\
\hline Not married & 25 & 20.32 \\
\hline Married & 98 & 79.68 \\
\hline Level of study & & \\
\hline Primary & 2 & 1.62 \\
\hline Secondary & 6 & 21.14 \\
\hline University & 95 & 77.24 \\
\hline Infertility duration & & \\
\hline [1-5] years & 60 & 48.79 \\
\hline [6-10] years & 32 & 26.01 \\
\hline [11-15] years & 12 & 9.75 \\
\hline 15 years or more & 19 & 15.45 \\
\hline Type of couple infertility & & \\
\hline Primary & 82 & 66.70 \\
\hline Secondary & 41 & 33.30 \\
\hline
\end{tabular}

A comparison of median TSH values between normal and abnormal subgroups for sperm parameters found no significant difference between the subgroups. The (Table 5) summarizes the results obtained.
Table 3: Semen characteristics of the study population.

\begin{tabular}{|c|c|c|}
\hline Modalities & $\begin{array}{l}\text { Frequenci } \\
\text { es }(n=123)\end{array}$ & $\%$ \\
\hline \multicolumn{3}{|l|}{ Semen } \\
\hline Normal & 37 & 30 \\
\hline Abnormal & 86 & 70 \\
\hline \multicolumn{3}{|l|}{ Volume } \\
\hline$\geq 1,5 \mathrm{ml}$ & 114 & 92.68 \\
\hline$<1,5 \mathrm{ml}$ & 9 & 7.32 \\
\hline \multicolumn{3}{|l|}{ Concentration } \\
\hline$\geq 15 \mathrm{millions} / \mathrm{ml}$ & 70 & 56.91 \\
\hline $10 ; 15$ millions $/ \mathrm{ml}$ & 11 & 8.94 \\
\hline $5 ; 10$ millions/ml & 14 & 11.38 \\
\hline $0 ; 5$ millions $/ \mathrm{ml}$ & 25 & 20.33 \\
\hline Azoospermia & 3 & 2.44 \\
\hline \multicolumn{3}{|l|}{ Progressive motility } \\
\hline Normal & 61 & 49.60 \\
\hline Abnormal & 59 & 47.97 \\
\hline \multicolumn{3}{|l|}{ Total motility } \\
\hline Normal & 62 & 50.41 \\
\hline Asthenozoospermia & 58 & 47.15 \\
\hline \multicolumn{3}{|l|}{ Vitality } \\
\hline Normal & 71 & 57.72 \\
\hline Necrozoospermia & 49 & 39.84 \\
\hline \multicolumn{3}{|l|}{ Multiple anomalies } \\
\hline Oligoasthenozoo spermia & 37 & 30.08 \\
\hline Oligonecrozoospermia & 36 & 29.27 \\
\hline Asthenonecrozoospermia & 47 & 38.21 \\
\hline Oligoasthenonecrozoospermia & 36 & 29.27 \\
\hline \multicolumn{3}{|l|}{ Normal forms } \\
\hline Normal & 120 & 97.56 \\
\hline Teratozoospermia & 0 & 0 \\
\hline
\end{tabular}

Table 4: Distribution of patients according to thyroid function and semen characteristics.

\begin{tabular}{|c|c|c|c|}
\hline & $\begin{array}{l}\text { Hypothyroidism } \mathbf{n}=\mathbf{5} \\
(\%)\end{array}$ & $\begin{array}{l}\text { Euthyroidism } \mathbf{n = 1 1 5} \\
(\%)\end{array}$ & $\begin{array}{l}\text { Hyperthyroidism } \mathbf{n}=\mathbf{3} \\
(\%)\end{array}$ \\
\hline \multicolumn{4}{|l|}{ Semen } \\
\hline Normal & $1(20)$ & $33(28.70)$ & $3(100)$ \\
\hline Abnormal & $4(80)$ & $82(71.30)$ & $0(0)$ \\
\hline \multicolumn{4}{|l|}{ Volume } \\
\hline$\geq 1,5 \mathrm{ml}$ & $5(100)$ & $106(92.17)$ & $3(100)$ \\
\hline$<1,5 \mathrm{ml}$ & $0(0)$ & $9(7.83)$ & $0(0)$ \\
\hline \multicolumn{4}{|l|}{ Concentration } \\
\hline$\geq 15$ millions/ml & $3(60)$ & $64(55.65)$ & $3(100)$ \\
\hline $10 ; 15$ millions $/ \mathrm{ml}$ & $0(0)$ & $11(9.57)$ & $0(0)$ \\
\hline 5;10 millions/ml & $1(20)$ & $13(11.30)$ & $0(0)$ \\
\hline $0 ; 5$ millions $/ \mathrm{ml}$ & $1(20)$ & $24(20.87)$ & $0(0)$ \\
\hline Azoospermia & $0(0)$ & $3(2.61)$ & $0(0)$ \\
\hline \multicolumn{4}{|c|}{ Progressive motility } \\
\hline Normal & $2(40)$ & $56(48.70)$ & $3(100)$ \\
\hline Abnormal & $3(60)$ & $59(51.30)$ & $0(0)$ \\
\hline
\end{tabular}




\begin{tabular}{|llll|}
\hline & $\begin{array}{l}\text { Hypothyroidism } \mathbf{n = 5} \\
(\%)\end{array}$ & $\begin{array}{l}\text { Euthyroidism } \mathbf{n = 1 1 5} \\
(\%)\end{array}$ & $\begin{array}{l}\text { Hyperthyroidism } \mathbf{n = 3} \\
(\%)\end{array}$ \\
\hline Total motility & $2(40)$ & $57(49.57)$ & $3(100)$ \\
\hline Normal & $3(60)$ & $55(49.83)$ & $0(0)$ \\
\hline Asthenozoospermia & & $3(100)$ \\
\hline Vitality & $3(60)$ & $65(56.52)$ & $0(0)$ \\
\hline Normal & $2(40)$ & $47(40.87)$ & $0(0)$ \\
\hline Necrozoospermia & & $0(0)$ \\
\hline Multiple anomalies & $2(40)$ & $35(30.43)$ & $0(0)$ \\
\hline Oligoasthenozoospermia & $2(40)$ & $34(29.57)$ & $0(0)$ \\
\hline Oligonecrozoospermia & $2(40)$ & $45(39.13)$ & \\
\hline Asthenonecrozoospermia & $2(40)$ & $34(29.56)$ & \\
\hline Oligoasthenonecrozoospermia & & & \\
\hline
\end{tabular}

Table 5: Comparison of normal and abnormal subgroups for sperm parameters according to medians of TSH.

\begin{tabular}{|c|c|c|c|}
\hline & & $\begin{array}{l}\text { Median of TSH }\left[1^{\text {st }} \mathbf{Q}-3^{\text {rd }}\right. \\
\text { Q] }\end{array}$ & P value (Mann-Whitney test) \\
\hline Volume & $\begin{array}{l}\text { Abnormal } \\
\text { Normal }\end{array}$ & $\begin{array}{l}1.440[1.065-2.345] \\
1.550[1.070-2.300]\end{array}$ & 0.938 \\
\hline Sperm concentration & $\begin{array}{l}\text { Abnormal } \\
\text { Normal }\end{array}$ & $\begin{array}{l}1.500[1.220-2.17] \\
1.550[0.980-2.313]\end{array}$ & 0.507 \\
\hline Sperm count & $\begin{array}{l}\text { Abnormal } \\
\text { Normal }\end{array}$ & $\begin{array}{l}1.495[1.195-2.017] \\
1.570[1.019-2.625]\end{array}$ & 0.909 \\
\hline Progressive motility & $\begin{array}{l}\text { Abnormal } \\
\text { Normal }\end{array}$ & $\begin{array}{l}1.590[1.180-2.430] \\
1.550[1.063-2.300]\end{array}$ & 0.544 \\
\hline Total motility & $\begin{array}{l}\text { Abnormal } \\
\text { Normal }\end{array}$ & $\begin{array}{l}1.545[1.098-2.367] \\
1.530[1.070-2.300]\end{array}$ & 0.571 \\
\hline Vitality & $\begin{array}{l}\text { Abnormal } \\
\text { Normal }\end{array}$ & $\begin{array}{l}1.590[1.055-2.155] \\
1.570[1.110-2.350]\end{array}$ & 1.000 \\
\hline Semen & $\begin{array}{l}\text { Abnormal } \\
\text { Normal }\end{array}$ & $\begin{array}{l}1.545[1.098-2.175] \\
1.440[0.947-2.300]\end{array}$ & 0.542 \\
\hline
\end{tabular}

Table 6: Results of the correlation coefficients between sperm parameters and TSH values in different groups.

\begin{tabular}{|lllll|}
\hline & $\begin{array}{l}\text { Hypothyroidism } \\
(\mathbf{n}=\mathbf{5}) \\
\text { Univariate analysis }\end{array}$ & $\begin{array}{l}\text { TSH } \\
\text { Hyperthyroidism } \\
(\mathbf{n}=\mathbf{3}) \\
\text { Univariate analysis }\end{array}$ & $\begin{array}{l}\text { Euthyroidism } \\
(\mathbf{n}=\mathbf{1 1 5}) \\
\text { Univariate analysis }\end{array}$ & $\begin{array}{l}\text { All patients } \\
\text { (n=123) } \\
\text { Univariate analysis }\end{array}$ \\
\hline Volume & $\mathrm{r}=0.158 \mathrm{p}=0.800$ & $\mathrm{r}=-0.500 \mathrm{p}=0.667$ & $\mathrm{r}=0.036 \mathrm{p}=0.705$ & $\mathrm{r}=0.030 \mathrm{p}=0.738$ \\
\hline Sperm count & $\mathrm{r}=0.900 \mathrm{p}=0.037$ & $\mathrm{r}=0.500 \mathrm{p}=0.667$ & $\mathrm{r}=-0.027 \mathrm{p}=0.774$ & $\mathrm{r}=-0.064 \mathrm{p}=0.465$ \\
\hline Progressive motility & $\mathrm{r}=0.800 \mathrm{p}=0.104$ & $\mathrm{r}=1.000 \mathrm{p}<0.001$ & $\mathrm{r}=0.031 \mathrm{p}=0.741$ & $\mathrm{r}=-0.059 \mathrm{p}=0.522$ \\
\hline Total motility & $\mathrm{r}=0.872 \mathrm{p}=0.054$ & $\mathrm{r}=1.000 \mathrm{p}<0.001$ & $\mathrm{r}=0.046 \mathrm{p}=0.648$ & $\mathrm{r}=-0.041 \mathrm{p}=0.136$ \\
\hline Vitality & $\mathrm{r}=0.359 \mathrm{p}=0.553$ & $\mathrm{r}=1.000 \mathrm{p}<0.001$ & $\mathrm{r}=0.032 \mathrm{p}=0.741$ & $\mathrm{r}=-0.033 \mathrm{p}=0.720$ \\
\hline Normal forms & $\mathrm{r}=0.400 \mathrm{p}=0.600$ & $\mathrm{r}=-1.000 \mathrm{p}<0.001$ & $\mathrm{r}=0.008 \mathrm{p}=0.939$ & $\mathrm{r}=-0.330 \mathrm{p}=0.729$ \\
\hline MAI* & $\mathrm{r}=-0.775 \mathrm{p}=0.225$ & $\mathrm{r}=-1.000 \mathrm{p}<0.001$ & $\mathrm{r}=-0.070 \mathrm{p}=0.489$ & $\mathrm{r}=-0.144 \mathrm{p}=0.136$ \\
\hline
\end{tabular}

*MAI: Multiple anomalies index

Determination of Spearman correlation coefficients found high and significant coefficients between TSH values and sperm parameters like sperm count, motility, vitality and morphology among patients with dysthyroidism but nonsignificant coefficients in euthyroid patients and in the total sample. Results are recorded in (Table 6).

\section{DISCUSSION}

In this study, we sought to determine the frequency of thyroid dysfunction, and to look for an association between TSH values and sperm parameters amongst African men managed for infertility of the couple at two reference hospitals of Yaoundé, in order to know if systematic screening thyroid disorders should be 
undertaken in our context. To answer this, we intend to successively discuss different aspects of our results.

Age negatively influences male fertility and this can be assessed when observing the time required for conception in a couple. ${ }^{19}$ However, before age 64, the spermatic parameters are not affected. ${ }^{20}$ The median age of the study population was 44 years [38 years; 50 years]. This result was in agreement with the literature. In fact, Moussa et al in Niamey also found an average of 44 years and Noumi et al in the west region of Cameroon obtained an average of 39 years..$^{21,22}$ We note that, in our setting, several patients delay and ultimately consult around 40 in context of couple's infertility. This could be due to the fact that a large proportion of African men are increasingly taking longer pursuing university studies, which postpones the average age at which they marry.

Almost half of the study population (48.8\%) has couple's infertility duration between 1 and 5 years. This result is similar to that Ikechebelu et al in south-eastern Nigeria, which found a median of 5 years in its study population. In addition, primary infertility of the couple was the most represented type in both study populations. In our series, $66.7 \%$ of couples had primary infertility as against the $65 \%$ their study revealed. ${ }^{23}$ These similarities may be due to the proximity of the recruitment zones.

As noted in the English study by Templeton et al couples with primary infertility are more likely to seek medical help, either through their family doctor or in a hospital. ${ }^{24}$ In the African setting, women suffering from primary infertility are generally subject to ostracism that drives them to quickly seek help..$^{25,26}$ This help can be sought in conventional or alternative medicine. Indeed, the absence of a child is a source of stress for the couple, but this stress is mitigated in case of secondary infertility: This could explain the existence of a high proportion of couples suffering from primary infertility in our sample and the fact that many of them were seeking medical help between 1 and 5 years of couple infertility.

Laboratory analysis of sperm samples found 9 cases $(7.3 \%)$ of hypospermia in our study. This proportion is lower compared to the findings of Mahamadou Traoré et al. in Mali (44\%). ${ }^{27}$ The difference is explained by the normal minimum value of the volume of sperm considered, this was $2 \mathrm{ml}$ in the study conducted in Mali and $1.5 \mathrm{ml}$ in ours.

The fact that we mainly recruited in a centre specialised in human reproduction influenced the type of patients we met because, for the most part, they were people who needed medical assistance at the time for reasons related to the husband or wife. All this explains why at microscopy we found an elevated proportion of patients with abnormal semen (70\%) and with oligoasthenonecrozoospemia (29.27\%). Nevertheless, these proportions were similar to those found in Noumi et al study in $2011 .^{22}$ In fact, they recruited in hospitals in
Western Cameroon and found only $23.2 \%$ of patients with normal semen.

We found a relatively low frequency of dysthyroidism in our study population. In fact, only $6.5 \%$ of the study population had dysthyroidism with $2.44 \%$ having subclinical hyperthyroidism and $4.06 \%$ subclinical hypothyroidism. No patient showed clinical signs in favour of dysthyroidism. These results are similar to those obtained by Lotti et al in 2016 in Italy. In a sample of 163 patients, they found $3.7 \%$ hyperthyroidism, $7.4 \%$ hypothyroidism and $88.9 \%$ euthyroidism. ${ }^{28}$ In addition, like in our study, the cases of dysthyroidism found were all subclinical. Clinical signs are usually present in patients with profound alterations in thyroid function. ${ }^{29}$ In our sample, profound alterations of thyroid function were non-existent. Therefore, in a population of patients followed for couple's infertility, men may be prone to subclinical thyroid disorders that are not usually accompanied by clinical signs.

Subclinical dysthyroidism, the definition of which is purely biological, has become a very common entity in daily clinical practice, but still generates controversy in the medical literature as to their clinical consequences and the potential benefits of treating it. ${ }^{30}$ According to data from the literature, we do not have a prevalence of dysthyroidism in our population. But, considering the English data, we found that in our sample although all cases of dysthyroidism were subclinical, the frequencies obtained were considerably higher than the prevalence observed in the general population, which are $0.01 \%$ for hyperthyroidism and $0.06 \%$ for hypothyroidism according to the Whickham survey of July 1995. ${ }^{31}$ The fact that frequencies obtained were considerably higher than the prevalence observed in the general population allows us to evoke an influence of dysthyroidism, even subclinical, on the male reproductive function whose main indicator is spermatic function.

Similarly, to the study of Poppe et al on thyroid disorder screening in subfertile men in 2006, we found that the percentage of dysthyroidism was higher in the subgroup of men with normal semen parameters $(4.65 \%$ in the abnormal semen subgroup and $10.81 \%$ in the normal one). ${ }^{32}$ Indeed, this result is paradoxical because one would expect the proportion of dysthyroidism to be higher in the subgroup of patients with abnormal semen parameters, which was not the case. However, considering the fact that the frequency of dysthyroidism in the population of men from infertile couples is higher than in the general population, suggesting an influence of thyroid function on reproductive function, the present result is rather in favour of the fact that the action of thyroid hormones on male reproductive function may use other pathways apart from spermatogenesis and that slight alterations of these hormones may not be the major determinants influencing spermatogenesis. Some data from literature confirms these hypotheses. Indeed, the clinical description of myxoedema patients in the 1962 
Griboff study clearly indicated that these patients had either a libido disorder or erectile dysfunction, and sometimes both, apart from semen anomalies. ${ }^{33}$ Furthermore, more recently in 2014, Khumar, Shekhar and Dhole showed, through a laboratory study, that there are thyroid hormone receptors not only on spermatogenic cells but also along the male genital tract and on the accessory glands. ${ }^{15}$

Using a dual approach, we sought for an association between semen parameters and TSH values. Comparison of different subgroups, normal and abnormal, for semen and its parameters using their TSH medians, by the Mann-Whitney test, found that the difference between their TSH medians was non-significant. But determination of the Spearman correlation coefficients found high and significant correlations between sperm parameters and TSH values in the subgroups of hypoand hyperthyroidism, and non-significant correlations in the euthyroid subgroup and total sample.

The non-significant correlations obtained in the total sample are consistent with data from literature. Indeed, the study conducted by Lotti et al in 2016 achieved similar results: There were no significant correlations between sperm parameters and TSH values in the total sample. ${ }^{28}$ But in our study, we went further to check if there were significant correlations in the subgroups of dysthyroidism. In fact, because we found significant correlations between TSH values and sperm parameters like sperm count, motility, vitality and morphology in patients with dysthyroidism, we can suggest that the influence of thyroid hormones on spermatogenesis would be more pronounced in cases of hypo- or hyperthyroidism. The fact that most of the clinical studies in populations with almost normal thyroid function failed to show a significant correlation, while those conducted on patients suffering from hypo- or hyperthyroidism showed a relationship, is in favour with our hypothesis. ${ }^{7,8,28,32,33}$ Moreover, in the euthyroid group of patients we did not observe any significant correlation. Thus, for normal TSH values, the spermatic parameters would manifest little or no influence, but an exit of TSH values from their limits of normality could induce abnormalities of spermatogenesis: such principles are frequent in our organism and that is what justifies the concept of homeostasis. Although the works of Jannini et al. in 2000 and those of Kumar, Shekhar and Dhole in 2014 clearly demonstrated the existence of thyroid hormone receptors on the testes, the present study is in favour of the fact that subclinical alterations of the thyroid function, even if they are not the major determinant of semen anomalies, may influence spermatogenesis. ${ }^{12,15}$ Thus, even if in the studies of Kidd et al dysthyroidism was incriminated as being the major aetiological factor of abnormalities observed at the sperm analysis, it is important to notice that these studies were conducted on patients seen in endocrinology departments and presenting deep alterations of thyroid function. ${ }^{7,8}$ Whereas, in our study, we found only subclinical cases.

\section{Limitations}

This study is the small number of patients with an abnormal thyroid function and the fact that we conducted a cross-sectional study that does not allow us to conclude on causality and mechanistic models involved: additional studies with larger samples are therefore needed to draw firm conclusions. Beyond all these, the strengths of this study lie in the fact that it was performed in a population of black Africans and data analysis was done using a clinical approach. Thus, we have been careful, when necessary, to use normal and abnormal subgroups for the different variables so as not to draw conclusions that would be of value only in statistics and have no direct clinical implications.

\section{CONCLUSION}

Frequency of dysthyroidism is low among African males from infertile couples and we noted significant correlations between TSH values and sperm parameters. Although the significant correlations found in this study reinforced the existence of an influence of thyroid function on the reproductive function and especially on spermatogenesis, the low frequency of thyroid dysfunction in our sample was not in favour of systematic screening for thyroid disorders during work-up of African males from infertile couples. However, this would be indicated in case of one or more clinical signs of dysthyroidism or for further assessment of the aetiology of an abnormal reproductive function.

\section{Funding: No funding sources}

Conflict of interest: None declared

Ethical approval: The study was approved by the Institutional Ethics Committee

\section{REFERENCES}

1. Hall JE. Guyton and Hall Textbook of Medical Physiology. 12th ed. London. Elsev Heal Scienc. 2012;910.

2. Wagner MS, Wajner SM, Maia AL. The role of thyroid hormone in testicular development and function. J Endocrinol. 2008;199(3):351-65.

3. Alahmar A, Dutta S, Sengupta P. Thyroid hormones in male reproduction and infertility. Asian Pac J Reprod. 2019;8(5):203.

4. Clyde HR, Walsh PC, English RW. Elevated plasma testosterone and gonadotropin levels in infertile males with hyperthyroidism. Fertil Steril. 1976;27(6):662-6.

5. Krassas GE, Papadopoulou F, Tziomalos K, Zeginiadou T, Pontikides N. Hypothyroidism Has an Adverse Effect on Human Spermatogenesis: A Prospective, Controlled Study. Thyroi. 2008;18(12):1255-9.

6. Hernández JJC, García JMM, García Diez LC. Primary Hypothyroidism and Human Spermatogenesis. Archiv Androl. 1990;25(1):21-7. 
7. Hudson RW, Edwards AL. Testicular function in hyperthyroidism. J Androl. 1992;13(2):117-24.

8. Kidd GS, Glass AR, Vigersky RA. The Hypothalamic-Pituitary-Testicular Axis in Thyrotoxicosis. J Clini Endocrinol Metabol. 1979;48(5):798-802.

9. Krassas GE, Perros P. Thyroid disease and male reproductive function. $\mathrm{J}$ Endocrinol Investigat. 2003;26(4):372-80.

10. Krassas GE, Poppe K, Glinoer D. Thyroid Function and Human Reproductive Health. Endocri Reviews. 2010;31(5):702-55.

11. Krajewska-Kulak E, Sengupta P. Thyroid Function in Male Infertility. Fronti Endocrinol [Inter]. 2013;4.

12. Jannini EA, Ulisse S, D’Armiento M. Thyroid Hormone and Male Gonadal Function. Endocrine Reviews. 1995 août;16(4):443-59.

13. Rajender S, Monica MG, Walter L, Agarwal A. Thyroid, spermatogenesis, and male infertility. Front Biosci (Elite Ed). 2011;3:843-55.

14. Jannini EA, Crescenzi A, Rucci N, Screponi E, Carosa E, De Matteis A, et al. Ontogenetic Pattern of Thyroid Hormone Receptor Expression in the Human Testis. J Clinic Endocrinol Metabol. 2000;85(9):3453-7.

15. Kumar A, Shekhar S, Dhole B. Thyroid and male reproduction. Ind $\mathrm{J}$ Endocrinol Metabol. 2014;18(1):23.

16. Gurnell M, Halsall DJ, Chatterjee VK. What should be done when thyroid function tests do not make sense?: Atypical thyroid function tests. Clinic Endocrinol. 2011;74(6):673-8.

17. Garber JR, Cobin RH, Gharib H, Hennessey JV, Klein I, Mechanick JI, et al. Clinical Practice Guidelines for Hypothyroidism in Adults: Cosponsored by the American Association of Clinical Endocrinologists and the American Thyroid Association. Thyro. 2012;22(12):1200-35.

18. World Health Organization, editeur. WHO laboratory manual for the examination and processing of human semen. 5th ed. Geneva: World Health Organization; 2010;271.

19. Hassan MAM, Killick SR. Effect of male age on fertility: evidence for the decline in male fertility with increasing age. Fertili Sterili. 2003;79:1520-7.

20. Gallardo E, Simón C, Levy M, Guanes PP, Remohí J, Pellicer A. Effect of age on sperm fertility potential: oocyte donation as a model. Fertili Sterility. 1996;66(2):260-4

21. Moussa D, Soumana A, Amadou SM, Soli I, Tahirou I, Ali A. Profil hormonal chez l'homme en cas d'infertilité au laboratoire de radio immunologie de l'institut des radioisotopes de Niamey. Afric J Urol. 2016;22(4):305-9.

22. Noumi E, Florentin Eboule A, Nanfa R. Traditional health care of male infertility in bansoa, west Cameroon. Int J Pharm Biomed Sci. 2011;2(2):42-50.

23. Ikechebelu J, Adinma J, Orie E, Ikegwuonu S. High prevalence of male infertility in southeastern Nigeria. J Obstet Gynaecol. 2003;23(6):657-9.

24. Templeton A, Fraser C, Thompson B. The epidemiology of infertility in Aberdeen. Brit Med J. 1990;301(6744):148-52.

25. Chachamovich JR, Chachamovich E, Ezer H, Fleck MP, Knauth D, Passos EP. Investigating quality of life and health-related quality of life in infertility: a systematic review. J Psychosom Obstet Gynecol. 2010;31(2):101-10.

26. Cui W. Mother of nothing: the agony of infertility. Bulletin of the World Health Organization. 2010;88(12):881-2.

27. Traore M, Toure A, Sissoko S, Samake NF. Profil spermiologique des hommes infertiles au Mali. Androlog. 2008;18(4):253-7.

28. Lotti F, Maseroli E, Fralassi N, Degl'Innocenti S, Boni L, Baldi $\mathrm{E}$, et al. Is thyroid hormones evaluation of clinical value in the work-up of males of infertile couples? Hum Reproduct. 2016;31(3):518-29.

29. Melish JS. Clinical Methods: The History, Physical, and Laboratory Examinations. 3rd ed. Boston: Butterworths. Chapter 135, Thyroid Disease. 1990;637-42.

30. Goichot B, Luca F. Dysthyroïdies infracliniques. La Presse Médic. 2011;40(12):1132-40.

31. Vanderpump MPJ, Tunbrldge WMG, French JM, Appleton D, Bates D, Clark F, et al. The incidence of thyroid disorders in the community: a twenty-year follow-up of the Whickham Survey. Clinic Endocrinol. 1995;43(1):55-68.

32. Poppe K, Glinoer D, Tournaye H, Maniewski U, Haentjens P, Velkeniers B. Is systematic screening for thyroid disorders indicated in subfertile men?. Europe J Endocrinol. 2006;154(3):363-6.

33. Griboff SI. Semen Analysis in Myxedema. Fertili Sterili. 1962;13(5):436-43.

Cite this article as: Ngowa JDK, Ngaha TYS, Voundi EV, Toukam M, Ngassam A, Noa CC, et al. Is thyroid stimulating hormone titration mandatory in the routine work-up of African males from infertile couples?. Int J Reprod Contracept Obstet Gynecol 2020;9:4337-43. 